\title{
A Class Exploring Current Events through a Psychological Lens
}

\author{
Stacey-Ann Baugh ${ }^{1, *} \&$ Debbie Van Camp ${ }^{1}$ \\ ${ }^{1}$ Department of Psychology, Trinity Washington University, Washington DC, 20017, USA \\ *Corresponding author: Department of Psychology, Trinity Washington University, 125 Michigan Ave NE, \\ Washington DC, 20017, USA. E-mail: baughs@trinitydc.edu
}

Received: May 16, 2014 Accepted: February 23, 2015 Online Published: March 15, 2015

doi:10.5430/jct.v4n1p91 URL: http://dx.doi.org/10.5430/jct.v4n1p91

\begin{abstract}
Engagement with political, social, and civic issues is a fundamental hallmark of an educated population. However, the level of engagement among adolescents and young adults is considered by many to be below desirable levels. This article presents details of a Psychology in Current Events course designed to increase civic engagement through an exploration of the psychological theories relevant to topical issues. Issues explored included immigration, healthcare reform, gun control, and gay marriage. Students explored these topics using weekly readings, position papers, and an assigned debate. An evaluation of initial student perceptions of the course indicated that students responded positively to the course and in particular reported that the course did help them to engage more fully with the civic and political issues that were presented.
\end{abstract}

Keywords: civic knowledge; current events; civic engagement; psychological theories

\section{Introduction}

In the United States, the engagement of adolescents and young adults in the civic process is considered by many as being below desirable levels (Galston, 2003). More recently, this issue has been compounded by a high-school education system that is increasingly focused on test scores in reading and math, often at the expense of social studies curricula (Center on Education Policy, 2006). Therefore, educators may need to more explicitly tackle the task of educating students about civic issues at the college and university level. The goal of civic education within the classroom is to increase civic knowledge (the content of what citizens ought to know) and provide students with the critical thinking tools necessary for participation with the democratic process (Patrick, 2004). Kahne and Sporte (2008) demonstrated that classroom activities can have a major impact on students' civic participation. In particular, they found that allowing students to explore difficult topics within the classroom, without judgment, was especially advantageous. In addition, classroom discussions related to current issues including events taking place at the international level appear to be particularly valuable (Patrick, 2004). A course in psychology seems well suited to address the paucity of civic knowledge related courses (Chenneville, Toler, \& Gaskin-Butler, 2012) as well as encourage the open dialogue necessary to maximize the course's efficacy.

\subsection{Course Description}

A Psychology in Current Events course was developed and taught at a small, all-female, private, liberal-arts institution in the Mid-Atlantic region. There were no pre-requisites for the course and it fulfilled the civic knowledge requirement of the institutions general education curriculum. Therefore, although it was popular among psychology majors, it was open to all students of any level.

The course was designed to allow students to explore current political, social, and civic events within American society and sought to explain and understand them using relevant psychological theory. The course objectives as specified in the syllabus were to: (1) explain how psychological theories and principles relate to everyday life; (2) articulate how psychological principles can be applied to public policy issues; (3) generate psychologically appropriate solutions to problems or issues encountered in real-world settings; and (4) transfer knowledge from classroom learning and research findings to applied situations. In addition, the course was designed to introduce students to many of the laws and policies of the United States and the ways they differ from similar laws in other countries with a particular focus on those that materially impact students' daily lives. It was our hope that while the 
theories and concepts used were psychological, that the act of exploring current events through this lens would allow students to appreciate their importance and thus they would feel more engaged in the current event issues on a broader level.

The specific topics covered in the class are revised each semester to include the most relevant and current topics. For example, in Fall 2012 the topics covered included polarizing topics such as immigration, gun control, elections and the role of religion and race in politics, right to die, same-sex marriage and parenting, universal healthcare, marijuana \& drinking laws, and the death penalty; other included topics are more chronically relevant, such as body image and internet use (see Table 1 for a full list). The psychological theories and concepts used each week depended on the topic being explored. For example, we explored Kohlberg's levels of moral development when considering right to die issues. Addiction theories and research concerning non-verbal communication were included in the internet topic. When exploring body image issues we discussed eating disorder characteristics, the development of self-esteem in adolescence, and the beautiful is good stereotype (Goldman \& Lewis, 1977). The topic of immigration was explored with identity theories, in particular acculturation, ingroup bias, outgroup homogeneity, and realistic conflict theory (Campbell, 1965). The topic of the election focused on decision-making theories, in particular biases in the decision-making process, as well as intergroup dynamics.

The course was team taught by one clinical psychologist and one social psychologist. Both professors were present in all classes and supplemented one another's lectures as necessary. However, the division of topics between the professors was equal and based on their expertise. The first class period of each week was primarily an exploration of the topic; the instructors introduced the students to the topic, the related psychological theory, and research findings in a lecture format. This allowed us to dispel any myths and ensure that the students understood the issue that was under consideration that week. The lecture was followed by a teacher-led classroom discussion of the concepts presented and real-life examples and events that illustrate the concepts discussed. In the second class-period of each week, individual students presented opposing sides of controversial issues related to the week's topic (see Table 1) and led the classroom discussion that followed their presentations.

Table 1. Weekly Lecture Topics, Reading Topics, and Debate Questions for Fall 2012

\begin{tabular}{|c|c|c|}
\hline Topic & Focus of Reading & Debate Question \\
\hline Right to Die & $\begin{array}{l}\text { The distinction between active and passive } \\
\text { euthanasia. }\end{array}$ & Should assisted suicides be decriminalized? \\
\hline The Internet & Whether cyberbullying is related to gender. & Should cyber bullies be prosecuted? \\
\hline Body Image & $\begin{array}{l}\text { Pursuit of the perfect female body and } \\
\text { cultural differences in body perceptions. }\end{array}$ & $\begin{array}{l}\text { Should models be required to maintain a } \\
\text { minimum body weight? }\end{array}$ \\
\hline Drugs and alcohol & Drug use laws. & $\begin{array}{l}\text { Should the drinking age be reduced from } 21 \\
\text { to } 18 \text { ? }\end{array}$ \\
\hline Sex addiction & $\begin{array}{l}\text { Validity of sex addiction as a psychological } \\
\text { diagnosis. }\end{array}$ & $\begin{array}{l}\text { Should sex addiction treatment be covered by } \\
\text { insurance? }\end{array}$ \\
\hline Immigration & Impact of immigration on US society. & Should the DREAM act be passed? \\
\hline Healthcare & Analysis of healthcare as a right. & $\begin{array}{l}\text { Should there be mandatory health care } \\
\text { coverage for birth control and abortions? }\end{array}$ \\
\hline $\begin{array}{l}\text { Election issues I: } \\
\text { group processes }\end{array}$ & $\begin{array}{l}\text { Political affiliation as two different } \\
\text { definitions of what it means to be } \\
\text { American. }\end{array}$ & $\begin{array}{l}\text { Should individuals who have been } \\
\text { incarcerated be allowed to vote? }\end{array}$ \\
\hline $\begin{array}{l}\text { Election issues II: } \\
\text { race and religion }\end{array}$ & Atheists as a distrusted outgroup. & $\begin{array}{l}\text { Should the religion of a candidate play a role } \\
\text { in politics? }\end{array}$ \\
\hline Homosexuality & Biological basis of homosexuality & $\begin{array}{l}\text { Is it ethical to treat someone for } \\
\text { homosexuality? }\end{array}$ \\
\hline $\begin{array}{l}\text { Gay marriage and } \\
\text { gay parenting }\end{array}$ & $\begin{array}{l}\text { Legal issues surrounding marriage and the } \\
\text { impact of gay parents on children }\end{array}$ & $\begin{array}{l}\text { Should homosexual couples be allowed to } \\
\text { adopt children? }\end{array}$ \\
\hline $\begin{array}{l}\text { Mental health and } \\
\text { crime/gun control }\end{array}$ & $\begin{array}{l}\text { Relationship between mental illness, } \\
\text { suicidality, aggression, and rates of gun } \\
\text { ownership. }\end{array}$ & $\begin{array}{l}\text { Should people with a history of mental illness } \\
\text { be allowed to own a firearm? }\end{array}$ \\
\hline Violent offenders & Characteristics of female offenders. & Should there be a death penalty? \\
\hline
\end{tabular}




\subsection{Course Requirements}

\subsubsection{Weekly Readings}

Each week students completed assigned readings related to that week's topic. The focus of these readings related broadly to the topic under consideration (see Table 1) and each exposed students to some of the arguments and research findings surrounding the issue. Frequently, these readings were taken from the Taking Sides series published by McGraw Hill which presents readers with an overview of a controversial issue - for example whether sex can be addictive - and then excerpts from writings by experts on opposing sides of the issue. In order to ensure that students were exposed to a diversity of viewpoints we also selected readings from various professional journals. These readings had the additional benefit of exposing students to original psychology texts; such exposure can provide students with a model for how arguments should be constructed and supported (Van Camp \& Van Camp, 2013). Students were required to have completed the readings prior to the start of class. To encourage students to complete the readings and think critically about the material there were weekly online reading quizzes. The untimed quizzes consisted of multiple choice and true/false questions that assessed factual knowledge of the readings as well as more critical reading comprehension. The weekly quizzes represented $10 \%$ of a student's final grade.

\subsubsection{Position papers}

Students were required to write five 2-4 page position papers on topics of their choosing. The paper requirements specified that students take a stand on an issue closely related to the selected topic and then argue for this stance using supporting empirical evidence taken from either academic sources or credible news sources. Papers were due the week after the selected topic had been discussed and debated and were collectively worth $50 \%$ of a student's final grade

\subsubsection{Examining the Controversy}

We randomly assigned each student to one side of a controversial topic (see Table 1). The student was then required to argue for their assigned side of the issue during a classroom presentation using evidence and good argumentation. Following the presentation of both sides of the assigned issue, both students led the class on a general discussion of the presented issue. This approach exposed students to all sides of the debate topic equally and so encouraged critical and in-depth consideration of the topics. However, the focus remained on what the research data and theory suggest about an issue. The presentation was worth $30 \%$ of a student's final grade.

\subsubsection{Participation}

The instructors expected all students to participate actively in all classroom discussions. The professors carefully cultivated an atmosphere of comfort and openness from the start of the semester to encourage student engagement and respectful exchange of ideas. Both instructors assessed the students' participation by a combination of their attendance, contribution, and general level of attention. At the end of the semester, the instructors discussed each student and agreed upon a participation grade that represented $10 \%$ of a student's final grade in the course.

\section{Methods}

Thirty female students took the class in Fall 2012. Although specific demographics were not collected the institution serves primarily Black and Hispanic students of typical college age. The majority of the class was sophomore and junior level. Twenty-five students who were present during the last class session of the semester were administered a survey designed to assess their satisfaction with the course. Specifically, the survey asked whether they felt that the class had helped to increase their knowledge of the specific civic-issues covered in the class and whether they felt that they had experienced any changes in their attitudes towards these topics. In addition, questions asked students whether they felt that were now more able to consider alternative viewpoints, appreciate diversity, and understand politics/policy and its impact on individuals. The students responded to these questions along a 7-point response scale from 1 (not at all) to 7 (very much). Finally, the students expressed in their own words the overall impact the course may have had on them.

\section{Results}

Students expressed that the course did help them to consider alterative viewpoints, understand and appreciate the impact of politics and policies, understand the source of civic knowledge, think critically, and so forth (see Table 2). Particularly high were the students' ratings of the course's ability to help them appreciate diversity and similarly to 
appreciate the difference between the U.S. and other countries. The questions that asked students whether they had acquired knowledge about the key issues that the class covered suggested that-at least as far as student survey responses are indicative of effectiveness - the course was successful in its aim to increase their civic knowledge. Interestingly, the mean response was lower and variability higher for the questions assessing students' self-rated feelings of change of attitude on the issues covered. Again, while students' perceptions of changes in knowledge and attitudes should not be interpreted too strongly as anything other than their satisfaction with the course, this does suggest that perhaps the course was successful in increasingly knowledge but did not necessarily effect any attitude change. Therefore, according to the students' perceptions of their experience in the class, we were successful - the students state that they feel more able to appreciate different viewpoints, consider law and policy, and state increased knowledge in our specific issue areas, all without necessarily changing their opinions, which was not our goal.

Table 2. Means and Standard Deviations of Responses to Student Satisfaction Survey

$M$

To what extent has Psychology in Current Events increased your ability to:

Consider alternate viewpoints on social issues.

Appreciate diversity.

Understand the US political process.

Analyze the impact of government policies on communities and individuals.

Analyze the role of citizens in the political process.

Understand the US legal system.

Understand the differences between US laws and laws in other countries.

Understand the differences between US society and aspects of world societies.

Monitor and understand current events.

Think critically about political information and arguments.

Make judgments about public policy.

How much has the course increased your knowledge of legal issues surrounding:

Immigration.

Drugs and alcohol.

Healthcare.

Gay marriage.

Gay parenting.

Gun control.
$S D$

$\begin{array}{ll}6.16 & 1.07 \\ 6.52 & 0.87 \\ 5.88 & 1.24 \\ 6.08 & 1.15 \\ 5.83 & 1.27 \\ 5.88 & 1.27 \\ 5.92 & 1.15 \\ 6.48 & 0.77 \\ 6.36 & 0.86 \\ 6.12 & 1.01 \\ 6.33 & 0.82\end{array}$

$\begin{array}{ll}6.04 & 1.08\end{array}$

$5.92 \quad 1.18$

$6.12 \quad 1.04$

$\begin{array}{ll}6.33 & 0.87\end{array}$

$\begin{array}{ll}6.42 & 0.78\end{array}$

$6.04 \quad 0.91$

Has your stance/option changed towards the following:

The DREAM act (immigration act).

$\begin{array}{ll}4.28 & 2.72\end{array}$

$4.48 \quad 2.43$

$\begin{array}{ll}4.56 & 2.49\end{array}$

The healthcare reform bill (Obama care).

$4.60 \quad 2.47$

$5.57 \quad 1.62$

$4.96 \quad 2.17$

$5.04 \quad 2.49$

Students' own words express their perception that the course did indeed help them to engage in the civic and social issues presented. Students expressed that the class had encouraged them to be more aware of current social issues. For example, one student said, "this class has definitely encouraged me to keep up with current events, not only in the U.S. but also globally, and to compare and contrast our society with others", and another that "I feel I need to pay more attention to social issues and consider my opinion", other comments include "this class helped me realize that it's important to keep up with current events" and "I am very much more engaged with social issues. I think this class is excellent." In addition, other students seemed to express that the class at the very least encouraged them to 
consider the topics presented in more depth than they perhaps would have otherwise. For example, one student said "this class has made me more aware of all issues but also made me realize what I truly have strong opinions on" and another said "overall, this class has challenged me to think outside of the box, and think more critically about current event issues."

\section{Discussion}

This article presents Psychology in Current Events as a course that might serve to increase students' civic knowledge as well as their interest in and engagement with social issues. Using a mix of assigned readings, lectures, discussions, and papers, we sought to engage students with the issues surrounding current and relevant topics by examining them utilizing psychological theories. Results of the student survey suggested that students did experience increases in their self-perceived civic knowledge and engagement with social issues.

Though this paper presents some initial student satisfaction data as preliminary support for the course's efficacy, this data cannot be taken as conclusive support for the effectiveness of the course and future research should examine more objectively whether students demonstrate any real or lasting change in their knowledge or apparent engagement. Similarly, while the purpose of the class was not to effect a change in the students' opinions and the survey data suggests that only moderate changes at best did occur, a comparison of pre and post-semester attitudes would be useful.

\section{Conclusion}

In conclusion, the course Psychology in Current Events successfully provided an opportunity for student engagement with political and civic issues. It is likely that this course could be widely adopted in many tertiary institutions and though initially offered via the psychological department may likely be successfully implemented in other social science curricula.

\section{References}

Campbell, D.T. (1965). Ethnocentric and other altruistic motives. In D. Levine (Ed.), Nebraska. Symposium on Motivation (pp. 283-311). Lincoln, NE: University of Nebraska Press.

Center on Education Policy. (2006). From the capital to the classroom: Year four of the No Child Left Behind Act. Washington, DC: Center on Education Policy.

Chenneville, T., Toler, S., \& Gaskin-Butler, V. T. (2012). Civic engagement in the field of psychology. Journal of the Scholarship of Teaching and Learning, 12(4), 58-75.

Galston, W. (2003). Redirect civic education to spur political involvement. The Education Digest, 69(3), 4-11

Goldman, W., \& Lewis, P. (1977). Beautiful is good: Evidence that the physically attractive are more socially skillful. Journal of Experimental Social Psychology, 13, 125-130. http://dx.doi.org/10.1016/S0022-1031(77)80005-X

Kahne, J., \& Sporte, S. (2008). Developing citizens: The impact of civic learning opportunities on students' commitment to civic participation. American Educational Research Journal, 45, 738-766. http://dx.doi.org/10.3102/0002831208316951

Patrick, J. (2004). The civic mission of schools: Key ideas in a research-based report on civic education in the U.S. Teacher Librarian, 32(2), 26-28.

Van Camp, D., \& Van Camp, W. (2013). Using content reading assignments in a psychology course to teach critical reading skills. Journal of the Scholarship of Teaching and Learning, 13(1), 86-99. 